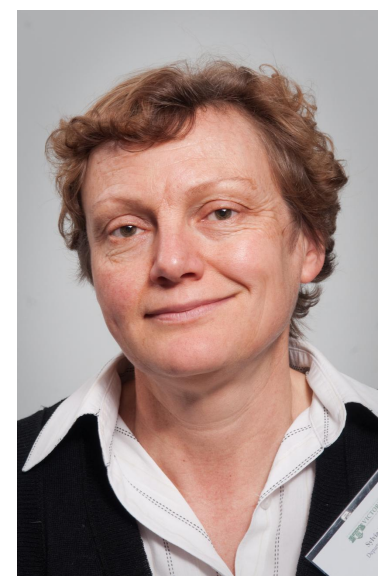

\title{
THE QUALITY OF \\ TEMPORARY JOBS: INSIGHTS \\ FROM THE SURVEY OF WORKING LIFE ${ }^{1}$
}

\author{
Sylvia Dixon \\ Department of Labour
}

\begin{abstract}
This paper discusses some of the insights that can be gained from the Survey of Working Life (2008) on the main features of temporary employment, the reasons that are given for working in a temporary job, and the pay and conditions of temporary employees. In the March 2008 quarter 9.4 percent of employees were working in temporary jobs. Most of the older adults and more than half of the young adults who were employed on a temporary basis indicated that they preferred temporary work, while prime-aged adults were roughly equally divided between preferring temporary work and wanting a permanent job. There were substantial differences between temporary and permanent employees in the job quality indicators considered, but also substantial differences among the four main types of temporary worker (casual, fixed-term, temporary employment agency and seasonal).
\end{abstract}

\section{Introduction}

This article presents some of the insights into temporary employment that can be gained from the 2008 Survey of Working Life (SoWL). The article focuses on three questions. First, are most temporary workers working in a temporary job from choice, or would they prefer a permanent job? Second, how do the pay and employment conditions of temporary employees compare with those of permanent employees? Three dimensions of pay and conditions are considered: hourly wages, training rates, and employment at non-standard times of the day or week. Third, what are the reasons for the differences in pay and conditions between temporary and permanent employees? To what extent are they due to differences in skill-related characteristics and the distribution of temporary and permanent workers across occupations and firms?

Past research on temporary work in New Zealand has yielded a picture of diversity, with temporary work incorporating both skilled and highly paid jobs and unskilled and poorly paid jobs. After interviewing employment agency temps in Auckland, Alach and Inkson, 2003, reported that most of those interviewed preferred temporary work, felt that their prospects for securing continuing work were good, and saw temping as a useful strategy for both personal and professional development. The agency temps in their study reported high levels of job satisfaction in the main. In contrast, when Harris and Harvey (2007) examined working practices in five industries where casual employment is common (stevedoring, cleaning, home-based aged care, hotels restaurants and cafes, and call-centres), they identified a number of factors associated with poorer job quality, including a lack of training opportunities, a lack of pathways into permanent work, shift work patterns that are disruptive to personal and family wellbeing, variability in hours or last-minute changes to workers' shifts or hours, insecurity regarding future work assignments, and difficulties in accessing sick or bereavement leave (ibid, p.4).

Previous research into temporary employment in New Zealand has been impeded by a lack of good statistical evidence. Past studies have either used qualitative methods to study particular occupations or industries (eg Alach and Inkson, 2003; Harris and Harvey, 2007) or analysed evidence from small-scale surveys (eg, McLaren and Dupuis, 2006). The Survey of Working Life gathered data on temporary work from a large and representative sample of employed New Zealanders, providing more reliable estimates of the numbers and characteristics of temporary workers than previously available. The large sample size allows comparisons to be drawn between different types of temporary work as well as between temporary and permanent workers. Although the survey did not gather information on all dimensions of job quality it covered many of the most important dimensions. The development of the Survey of Working Life has made an important contribution to the evidence base that future research into temporary employment can draw on. ${ }^{2}$

The paper is structured as follows. Section 2 provides essential background information on the survey and the way in which temporary employment was defined and measured. Section 3 briefly describes the incidence of 
each of the main types of temporary employment and the characteristics of temporary workers. Section 4 discusses the reasons that were given for working in temporary jobs and whether temporary workers would prefer permanent employment. Section 5 compares the wages, training rates, and working time patterns of temporary and permanent workers. Section 6 discusses factors that contribute to the lower pay and lower training rates of temporary employees, and assesses the role of differences in skill-related personal attributes and job characteristics. Section 7 concludes.

\section{The survey and its definition of temporary employment}

The Survey of Working Life is a Statistics New Zealand survey that gathers job-related data from a representative sample of employed New Zealanders through a supplement to the Labour Force Survey. It was carried out for the first time in the March 2008 quarter. All respondents to the March 2008 quarter HLFS who were employed in the reference week were asked to answer the SoWL questions. Responses were obtained from approximately 14,500 individuals.

The concept of temporary work is used in the survey to cover all types of short-term work that are undertaken by employees, including fixed-term jobs, casual jobs, seasonal jobs, and jobs arranged through temporary employment agencies. A job is defined as temporary if the worker does not have any expectation of continuous long-term employment. A temporary employee can be an employee who has been hired for a specific time period or until the completion of a specific project; someone who is temporarily replacing another worker who is absent; someone who is filling a seasonal job; or someone who is employed only when needed by their employer. This definition includes casual employment and seasonal employment. Jobs undertaken by people who are selfemployed are not included in the definition.

Each employee in the survey was asked if they were employed on a permanent basis (focusing on their main job if they held more than one job). This question was worded as follows:

'A permanent employee is guaranteed continuing work. They can stay in their job until they decide to leave or their employer makes them redundant. In your job, are you a permanent employee?'

Employees who said that their job was not permanent were then asked a series of additional questions designed to identify the nature of their employment relationship, so that they could be classified as a fixed-term employee, a casual worker, a temporary employment agency worker, or in some other type of employment relationship. ${ }^{3}$ All employees, including those who said that their job was permanent, were also asked whether their job was only available at certain times of the year, ie seasonal. People who initially said that their job was permanent but later indicated that their job was seasonal were classified as temporary because seasonal jobs do not provide continuous work throughout the year. The full set of questions used to identify and classify temporary employees is given in Appendix 1.

Previous qualitative research in New Zealand has shown that many temporary employees do not have a good understanding of the terms and conditions of their employment or the meaning of terms like 'casual'. The SoWL did not ask respondents to choose between the different types of temporary work and instead classified them using their responses to more concrete questions such as 'were you hired to temporarily replace another worker?'. However, this strategy did not eliminate the potential for confusion, which means there is likely to be some measurement error in the survey's estimates of temporary employment numbers.

\section{Numbers and characteristics of temporary workers}

Approximately one in ten, or 9.4 percent, of employees were working in temporary jobs when interviewed in the March 2008 quarter. ${ }^{5}$ One in twenty (4.9 percent) were employed on a casual basis, 2.3 percent were employed on a fixed-term contract, and 0.7 percent worked for a temporary employment agency. The remaining 1.5 percent could not be classified to a particular type of temporary job contract using the information collected in the survey. The majority of this latter group were seasonal employees who initially said they were permanent employees but later gave a 'yes' response when asked if their job was only available at certain times of the year, ie seasonal. ${ }^{6}$ In total, 2.7 percent of employees (and 28 percent of temporary employees) were identified as being seasonal workers through the seasonal work question.

The incidence of temporary employment by gender and age group is summarised in table 1 . The numbers indicate that female employees are more likely than male employees to be working in temporary jobs: their rate was 11 percent compared with 8 percent for men. Temporary employment is substantially more common among young employees than most other age groups with the exception of 65 years and over. Seventeen percent of youth employees and 17 percent employees the ' 65 plus' age group were employed in temporary jobs, compared with just 7-8 percent of employees in the 25-64 year age groups.

Although the incidence of temporary employment is similar for men and women in the ' $15-24$ ' and ' 55 plus' age groups, it diverges substantially in the intervening years. Female employees in the 25-54 year age range were about twice as likely to be in temporary work as prime-aged male employees (10 percent compared with 5 percent). Detailed analysis of the incidence rates by five year age group indicated that the gender gap in the likelihood of working in a temporary job was largest in the 35-39 and 40-44 year age groups, where 3-4 percent of male employees but 10-11 percent of female employees held temporary jobs. 
Māori employees were more slightly likely to be working in temporary jobs than workers of other ethnic groups (11.5 percent compared with 9.0 percent of Europeans and 8.9 percent of Māori/European). The results for people with different levels of educational qualification indicate that the relationship between education and the incidence of temporary work is complex. The proportion in temporary jobs is relatively high among employees with no qualifications, but it is also relatively high among workers with degrees. It is lower for employees at intermediate educational levels.

The incidence patterns also differ for different types of temporary work. Young adults are particularly likely to be employed in casual jobs, while prime-aged employees are more likely to be in a fixed-term arrangement. Employees with post-school qualifications are also more likely to be working in a fixed-term job than those with lower levels of education. The incidence of fixed-term employment was 4.4 percent for employees with a degree but only 1.2 percent for employees with no qualifications.

The characteristics of temporary employees and their jobs are summarised in tables 2 and 3. Slightly over half of all temporary employees were female. More than one third were youth workers (ie males or females aged under 25 years), and another one third were women aged between 25 and 54. Prime-aged men made up about 17 percent, and older men and women comprised the remainder, around 15 percent. Other analyses of the survey data showed that compared with permanent employees, temporary employees were significantly younger (by 4 years on average), more likely to be living in a minor urban area or rural location, less likely to be married or living with a partner, less likely to have dependent children, and less likely to hold an educational qualification (Dixon, 2009). Some of these differences were relatively small.

Roughly half of all temporary employees worked parttime hours compared with only 20 percent of permanent employees. This is one of the most striking of the differences between temporary and permanent employees in job characteristics (shown in table 3). Among temporary workers, casual workers were the subgroup most likely to be employed on a part-time basis: 61 percent were working part-time hours. Fixed-term employees were the group most likely to be employed full-time (70 percent worked full-time hours). ${ }^{7}$

\section{Preferences for temporary employment}

Do people work in temporary jobs because they prefer a temporary arrangement or simply because they are not able to obtain a suitable permanent job? The survey included two questions that shed some light on this question.

First, temporary employees were asked their reasons for undertaking temporary or seasonal work. The question was open-ended, and multiple responses were recorded if given. The results are summarised in table 4. The responses were diverse, with no single reason dominating.
Thirteen percent indicated that they were working in a temporary job because they were not able to find a permanent job, or said they hoped or expected their temporary job to become permanent. Nine percent indicated that they worked in a temporary job for family reasons, for example to manage childcare responsibilities, or because of certain family obligations or family circumstances. Twenty four percent said they worked in a temporary job because they were studying or wanted to gain work experience. Fifteen percent gave lifestyle reasons, such as only wanting to work for a short period of time, or enjoying the variety that short-term jobs offer. Nine percent cited financial reasons, such as the money being better in their temporary job. One percent referred to health limitations as a reason for working in a temporary job. These results suggest that perhaps 13 percent of temporary workers were in temporary jobs on an 'involuntary' basis (the first group identified above). The true percentage could well be higher than 13 percent, however, if some of the people whose responses couldn't be classified were also working in temporary jobs primarily because they weren't successful in finding a suitable permanent job.

Second, temporary employees were asked if they would prefer to have a permanent job. Forty percent said 'yes' to this question. Fifty-three percent said they would prefer to continue doing temporary or seasonal work, and approximately 7 percent did not know or did not give a response. The proportion who said they would prefer a permanent job (40 percent) could be interpreted as an alternative measure of 'involuntary' temporary work, although this interpretation is debateable, as it is unclear how the question was answered by respondents. Some may have thought about their ideal employment arrangement rather than the one they would actively seek at present, given their current circumstances.

Similar proportions of men and women in temporary jobs said they would prefer to have a permanent job. Almost half of all fixed-term employees and temporary agency workers did so. The proportion who said they would prefer a permanent job was much lower among casual and seasonal employees (37 percent and 36 percent respectively). In most types of temporary work, primeaged adults were much more likely than young adults or older adults to say that they would prefer a permanent job.

A regression model was estimated to identify the personal and job characteristics that are most strongly associated with the preference to work in a permanent job, holding the effects of other characteristics constant. The results (not shown in this paper) indicate that age, full-time hours and job tenure are significant predictors of wanting a permanent job. Teenagers, those aged 60 or over, those who were working on a part-time basis, and those with longer tenure in their jobs, were significantly less likely to say they would prefer a permanent job than employees in the prime age groups, the full-time employed, and those with shorter job tenure. There were no statistically significant differences between casual, fixed term, agency and seasonal workers in the likelihood of wanting permanent work, indicating that temporary job type does 
not have a major impact once differences in personal characteristics are held constant. ${ }^{8}$

In other countries, temporary workers have tended to report a lower level of job satisfaction than permanent employees (Booth et al 2002, Wooden and Warren, 2003). ${ }^{9}$ In the SOWL this was also the case, but the differences were too small to be consequential. Eightyone percent of temporary workers and 84 percent of permanent workers said they were satisfied or very satisfied with their job. Six percent of temporary workers said they were dissatisfied or very dissatisfied, compared with 5.0 percent of permanents.

In summary, the results indicate that preferences for temporary work vary strongly by age. Prime-aged adults (those aged from 25-54 years) were almost equally divided between preferring temporary work and wanting a permanent job. The vast majority of the older adults (55 years and over) and more than half of the younger adults (15-24 years) who held temporary jobs said they preferred temporary work.

\section{Pay and employment conditions}

In this section we discuss the status of temporary workers in terms of three job quality indicators: pay rates, training, and the requirement to work at non-standard times of the day or week.

There is a substantial pay gap between temporary and permanent employees. In the March 2008 quarter the average hourly earnings of temporary employees were $\$ 18.50$ per hour, which was just 79 percent of the average hourly earnings of permanent employees (\$23.40). However, there was considerable variation in earnings across the different types of temporary work (see table 5). Casual employees had the lowest mean hourly earnings (\$16.00 per hour). Fixed-term employees had the highest mean hourly earnings ( $\$ 23.70$ per hour) and were on average paid slightly more than permanent employees.

Measures of the share of workers with relatively low and relatively high pay are also shown in table 5. Forty-four percent of temporary employees earned less than $\$ 15$ per hour, compared with 24 percent of permanent employees. Casual workers were the lowest paid group of temporaries, with 55 percent earning less than $\$ 15$ per hour and only 9 percent earning $\$ 25$ or more per hour. The earnings distribution of fixed-term employees was similar to that of permanent employees.

Temporary employees were much less likely than permanent employee to have received training. Just eighteen percent of temporary employees, compared with 32 percent of permanent employees, said they had undertaken some employer-funded study or training in the last twelve months. Among those who had received employer-funded training, temporary employees were more likely than permanent employees to have trained for one day or less, and less likely to have trained for 6 days or more. Again, there were substantial differences across the different types of temporary employment. Fixed-term employees were most likely to have studied or trained: their participation rate was similar to that of permanent employees. The education and training rate was lowest among casual workers (13 percent) and temporary agency workers (10 percent). Women working in temporary jobs were substantially more likely to have received employerfunded study or training than men, reflecting differences in age composition, skills and job mix.

It is important to note that the differences in training rates that were recorded across the different types of employee will have been influenced by differences in job tenure and labour force participation during the reference year. If casual employees were on average employed for fewer weeks of the previous year than other types of employee, for example, this would directly reduce their opportunities to receive employer-funded training. Other factors contributing to the differences in training rates by type of employment contract include differences in age, job tenure, hours of work, educational level, and occupation.

Turning to working time patterns, the survey results show that casual and seasonal employees were more likely than permanent employees to say that they usually did at least some of their work outside the conventional working week (defined as $7 \mathrm{am}$ to $7 \mathrm{pm}$, Monday to Friday). This was true for 43 percent of casuals and 45 percent of seasonal workers. In addition, casual and seasonal workers were more likely than permanent workers to have worked at non-standard times, on one or more occasions, during the last month.

When specific non-standard times are considered, it appears that casual workers were more likely than permanent employees to have worked during the evening or on the weekend, and seasonal workers were more likely to have worked in the early morning or on the weekend, during the last four weeks. In contrast, fixed term and temporary agency employees were less likely than permanent employees to have worked on the weekend, and they had similar or lower rates of evening, night and early morning work.

Overall there are substantial differences between temporary and permanent employees in wage rates, training participation and working time patterns, but also substantial differences in pay and conditions between the different types of temporary work.

\section{Reasons for the differences in pay and training outcomes}

Although temporary employees have quite different employment outcomes than permanent employees on average, it would be a mistake to assume these differences are necessarily due to the temporary nature of the employment contract or the short-term duration of the employment relationship. Temporary workers differ from permanent workers on a variety of other characteristics that are correlated with differences in skills and earnings potential, such as age, work experience, employment continuity, education, occupational skills, and hours of 
work. They also differ in their distribution across different types of jobs and firms.

To estimate the wage penalty or wage premium that is associated with temporary employment, a common approach is to use a statistical model to adjust the actual wage gap between temporary and permanent employees for the effects of differences in skill-related and job characteristics. The 'adjusted' wage gap can then be interpreted as the difference in pay that is due to the temporary nature of the job. However, due to the fact that temporary and permanent employees are likely to differ in a variety of ways that are not measured in surveys (and therefore can't be included in the adjustment) this approach has some significant limitations.

Recent studies of the earnings and training rates of temporary workers have used longitudinal data containing evidence on the changes in pay that employees experience when they move between temporary and permanent jobs. These longitudinal data sources offer greater potential for isolating the effects of temporary employment from the effects of other correlated factors than is offered by cross-sectional surveys like the SoWL. If there is a pay penalty for temporary work, for example, individuals who move from permanent to temporary jobs should on average suffer pay reductions, while individuals who move from temporary to permanent jobs should on average experience pay increases. If some types of temporary jobs offer higher pay rates, it should also be possibly to identify the size of those wage premiums from the evidence on the pay changes that occur when individuals move between jobs.

A paper by Bono and Weber (2008) which examines the wages of seasonal employees in Austria is a good example of recent research using this analytical strategy. The seasonal workers in their sample earned 3 percent less than non-seasonal workers on average. After taking other factors into account through their longitudinal model, however, Bono and Weber estimated that the seasonal workers actually earned an 11 percent wage premium (relative to what they would have earned in nonseasonal jobs).

The scope for understanding and measuring the factors driving the pay and training gaps between temporary and permanent workers in New Zealand is limited by the nature of the currently available data, but some useful insights can still be gained.

\section{Hourly earnings}

The contribution of demographic, educational, and job characteristics to the temporary-permanent gap in average hourly earnings was explored by estimating earnings regressions. The dependent variable was average hourly earnings. The initial regression model included an indicator for temporary job status (to measure the relationship between temporary employment and earnings) and controls for individual characteristics (age, ethnicity, parental status, immigrant status, geographical location, and highest educational qualification). In a second regression model, measures of job and firm characteristics were also included: hours of work, occupation defined at one-digit level, industry defined at one-digit level, the employer's business type (defined using indicator variables for public sector and non-profit organisations), and the size of the employer's enterprise. Controls for the individual's job tenure were not included because job duration is likely to be determined jointly with temporary job status. Full details of the regression models are given in Dixon (2009).

Table 6 shows the key estimates obtained. ${ }^{10}$ The first column of the table shows the unadjusted or 'raw' $\log$ wage gap between all temporary employees, or a particular subgroup of temporary workers, and permanent employees. The numbers are negative because working in a temporary job is associated with lower wages. The second column gives the estimated log wage difference associated with temporary work once the effects of differences in individual characteristics have been controlled for. Controlling for personal characteristics dramatically reduces the size of the temporary-permanent gap in log hourly earnings. For instance, there is a 64 percent reduction in the wage gap estimated for all male temporary workers (which declines from 30 percent to approximately 11 percent), and a 44 percent reduction in the wage gap estimated for all female temporaries (which declines from 13 percent to 7 percent). Temporary employees are younger and less qualified than permanent employees on average, and controlling for these and other differences in personal characteristics reduces the wage 'penalty' that is associated with the temporary work indicators in the regression estimates.

The results in the third column of table 6 show that controlling for job characteristics as well as personal characteristics further reduces the estimated wage penalty associated with temporary work. For all temporary and most subgroups of temporary employees, there is no longer a statistically significant difference between the average wages of temporary and permanent employees. Female casual workers are the exception to this pattern: they are estimated to earn approximately 6.5 percent less than females in permanent jobs after taking the effects of individual and job characteristics into account.

This analysis indicates that the temporary-permanent gap in average hourly wages can be largely attributed to differences in measured demographic, educational, and job characteristics. The main exception is that we continue to find that a small wage penalty is associated with casual work for women. However, our analysis has not been able to take account of a number of other factors that prior research findings suggest may influence the casual/non-casual wage differential, such as differences in previous work experience and unmeasured differences in aspirations and skills.

Overall, the results indicate that most temporary workers earn roughly the same amount per hour as 'similar' permanent workers (those statistically matched on the basis of their personal and job characteristics). This suggests that temporary workers in New Zealand are not 
widely employed at lower rates of pay than permanent employees purely on the basis of their type of employment relationship. ${ }^{11}$

\section{Training}

To estimate the effect of working in a temporary job on the probability of receiving employer-funded training, the probability of having received training in the last year was modelled using logistic regressions. The dependent variable in these regressions is an indicator variable that is set to ' 1 ' if the individual received employer-funded training during the last 12 months and to ' 0 ' otherwise. Initially, we modelled the training participation probability of men and women as a function of their measured personal characteristics (age, ethnicity, parental status, immigrant status and years in New Zealand, geographical location and highest educational qualification) and temporary job status. In a second regression, the following job characteristics were added to the explanatory variables: hours of work, occupation defined at one-digit level, industry defined at one-digit level, size of employer, and the employer's business type (private sector, public sector or non-profit sector). We did not control for variations in job tenure because this is likely to be determined jointly with temporary job status. In addition, we were unable to control for any differences across individuals in the number of weeks and months that they worked during the previous year. Variations in weeks worked can be expected to have a direct impact on our measure of training rates (because people who worked for fewer weeks would have had less time in which to receive training, all else being equal).

Table 7 presents the key results obtained. The first column of the table shows the unadjusted or raw percentage point gap in training rates between all temporary employees (or a particular subgroup of temporary employees) and permanent employees. The second column shows our estimates of the marginal effect of temporary employment on the probability of having received training, after controlling for personal characteristics. The third column shows our estimates of the marginal effect of temporary employment on training rates after both personal and job characteristics are included in the regression model. These 'marginal effect' estimates represent the difference between the predicted training participation rates of temporary and permanent employees, calculated while holding the effects of other variables constant. $^{12}$

Most of the marginal effects shown in table 7 are negative and statistically significant. The results given in the third column indicate that the predicted training probabilities of all male temporary employees, and each sub-group of male temporary employees, remain substantially lower than those of permanent employees after adjustments for both personal and job characteristics have been made. For example, the training probability for all temporary males is estimated to be approximately 15 percentage points lower than that for males in permanent employment. The unadjusted difference was 21 percentage points, indicating that about one quarter of the gap in training can be explained by differences in personal and job characteristics. The estimated training probabilities are also significantly lower for males in casual, fixed-term, and seasonal jobs.

Women in temporary jobs face a smaller gap in training rates than men, relative to women in permanent jobs, both before and after adjustments are made for differences in characteristics. In the results from the model with controls for both personal and job characteristics (shown in the third column), the estimated training probability for all females in temporary work is 5.6 percentage points lower than that for 'similar' female permanents in similar jobs. (The unadjusted difference was 9 percentage points.) Women in casual and temporary employment agency jobs have significantly lower training probabilities than those in permanent jobs, but for women in fixed-term jobs there is no significant difference.

As noted previously, temporary and permanent employees are likely to differ in their continuity of employment, and this can be expected to directly influence training rates when the reference period for measuring training participation is a lengthy period such as the previous year.

Summarising these results, the temporary-permanent gap in training rates appears to be partly due to differences in the personal characteristics of temporary and permanent employees. On average temporary employees are less highly educated than permanent employees and more likely to be aged under 25 years, and both these factors are correlated with a lower likelihood of receiving employer-funded training. Differences in job characteristics, including shorter hours, industry and occupation also make a contribution to the temporarypermanent training gap. These factors do not fully account for the lower training rates of temporary employees, however. It is likely that some of the remaining gap is due to the fact that temporary employees typically worked for fewer weeks in the previous year than permanent employees.

The finding that there is a significant association between temporary employment and a lower probability of having undertaken training is consistent with the hypothesis that employers offer less training to temporary workers. However it is also possible that there are unmeasured differences between temporary and permanent employees on other relevant factors, such as weeks worked during the year and the motivation to undertake training, that are contributing to the gap in participation rates. With only one observation for each respondent, we are unable to make any statistical adjustments for the effects of these unmeasured factors.

\section{Conclusion}

According to the Survey of Working Life, 9.4 percent of employees in the March 2008 quarter were working in a temporary job. By analysing the survey data on reasons and preferences, we found that most of the older adults and more than half of the young adults who were 
employed on a temporary basis indicated that they preferred temporary work. However, prime-aged adults (those aged 25-54) were roughly equally divided between preferring temporary work and wanting a permanent job. We also found that there are substantial differences between temporary and permanent employees in wage rates, training participation rates and working time patterns, but also substantial differences in pay and conditions between the different types of temporary work (fixed-term, temporary agency, casual and seasonal).

Our analysis of the permanent/temporary pay gap indicated that the lower average hourly earnings of temporary employees can be almost entirely attributed to differences in demographic characteristics and occupations and industries of employment. Temporary workers earn essentially the same amount per hour as permanent employees with matching demographic and job characteristics. Demographic characteristics, occupation and industry of employment also account for some of the gap in training between temporary and permanent employees, but a significant training rate gap remains unexplained.

\section{Notes}

1. Access to the data used in this report was provided by Statistics New Zealand under conditions designed to give effect to the security and confidentiality provisions of the Statistics Act 1975. The results presented in this study are the work of the author, not Statistics New Zealand.

2. The survey was designed to be repeated on a regular basis, at intervals of around 3 years.

3. People who gave more than one 'yes' response to the sequence of questions on the nature of their temporary job were classified to one job type using a prioritisation scheme (see Dixon, 2009).

4. WEB Research and Department of Labour (2004) identified this problem when interviewing informants in case studies of employment in cleaning, labour hire, fish processing and call centres.

5. People who had two or more jobs were classified according to their main job.

6. It is possible that the proportion of employees who work in temporary jobs is slightly higher in the March quarter than at other times of the year, because of seasonal jobs that exist only in the summer months.

7. More information on the jobs held by temporary employees and the types of firms they work for is given in Dixon (2009).

8. Full details are given in Dixon (2009).

9. Wooden and Warren (2003) report that casual employees in Australia are less satisfied with their jobs than permanent employees, but fixed-term employees are more satisfied.

10. We do not give estimates for males in temporary agency employment because of small sample sizes.
11. The finding that temporary employment is not generally associated with a wage rate penalty relates only to hourly compensation. Because temporary employees work fewer hours per week than permanent employees on average, their weekly and annual earnings are lower.

12. Because the logit model is non-linear the marginal effect of each independent variable is not constant, as in a linear regression model. Rather, it varies according to the values of all the other independent variables that are included in the model. In this paper we adopt the conventional approach to reporting the marginal effects of each independent variable by evaluating the probabilities at the sample averages for all other independent variables.

\section{References}

Alach, P. and Inkson, K. (2003). 'Temping: A study of temporary office workers in Auckland.' Research Report 2003/2, Labour Market Dynamics Research Programme, Massey University, Auckland.

Bono, E. D. and Weber, A. (2008). 'Do wages compensate for anticipated working time restrictions? Evidence from seasonal employment in Austria'. Journal of Labor Economics, vol. 26, no. 1 .

Booth, A, Francesconi, M and Frank, J (2002). 'Temporary jobs: Stepping stones or dead ends?'. Economic Journal 112(480), ppF189-F213, June.

Dixon, S. (2009). 'Temporary workers and their employment outcomes'. Department of Labour research paper.

Harris, P. and Harvey, O. (2007). 'Understanding casual and temporary work in New Zealand'. Unpublished report to the Department of Labour.

McLaren, E. and Dupuis, A. (2006). 'The employment experiences of permanent and temporary workers in a New Zealand study of young people'. Research Report 2006/5, Labour Market Dynamics Research Programme, Massey University, Auckland.

WEB Research and Department of Labour (2004). Report of exploratory case study research into precarious employment. Department of Labour research report,

http://www.dol.govt.nz/pdfs/precariousemployment.pdf

Wooden, M and Warren, D (2003). 'The characteristics of casual and fixed term employment: Evidence from the HILDA survey.' Melbourne Institute Working Paper No. 15/03. 
Table 1: The incidence of temporary work: Variations by demographic group

\begin{tabular}{c|c|c|c|c|c|c|}
\hline & Type of temporary work & & \\
\cline { 2 - 3 } Casual & Fixed-term & $\begin{array}{c}\text { Temp } \\
\text { agency } \\
\text { worker }\end{array}$ & $\begin{array}{c}\text { Other } \\
\text { (mainly } \\
\text { seasonal \& } \\
\text { not further } \\
\text { defined) }\end{array}$ & $\begin{array}{c}\text { All seasonal } \\
\text { employees }\end{array}$ & $\begin{array}{c}\text { All } \\
\text { temporary } \\
\text { employees }\end{array}$ \\
\hline
\end{tabular}

Proportion of employees whose main job was temporary

\begin{tabular}{|c|c|c|c|c|c|}
\hline All employees & 4.9 & 2.3 & 0.7 & 1.3 & 2.7 \\
\hline \multicolumn{6}{|l|}{ Gender } \\
\hline Male & 4.3 & 1.7 & 0.4 & 1.5 & 2.9 \\
\hline Female & 5.5 & 2.9 & 1.0 & 1.0 & 2.4 \\
\hline \multicolumn{6}{|c|}{ Age group (y ears) } \\
\hline $15-24$ & 10.9 & 2.8 & 1.0 & 2.1 & 5.3 \\
\hline $25-34$ & 2.9 & 2.8 & 0.8 & 1.1 & 1.8 \\
\hline $35-44$ & 3.4 & 2.2 & 0.5 & 0.9 & 2.1 \\
\hline $45-54$ & 2.8 & 1.8 & 0.7 & 1.3 & 2.1 \\
\hline $55-64$ & 4.0 & 1.8 & $\mathrm{~S}$ & 1.0 & 2.0 \\
\hline $65+$ & 11.6 & 2.4 & S & $\mathrm{S}$ & 3.6 \\
\hline
\end{tabular}

Gender by age group (years)

Males, 15-24

$\begin{array}{rrrrrr}11.4 & 3.0 & 0.7 & 3.0 & 6.5 & 18.4 \\ 2.0 & 1.3 & 0.3 & 1.1 & 1.7 & 4.8 \\ 5.3 & 1.5 & \mathrm{~S} & 1.7 & 3.2 & 9.3 \\ 10.3 & 2.5 & 1.4 & 1.1 & 4.1 & 15.9 \\ 4.2 & 3.3 & 1.0 & 1.1 & 2.2 & 9.7 \\ 5.2 & 2.2 & \mathrm{~S} & \mathrm{~S} & 1.3 & 8.5\end{array}$

Males, 55+

Females, 15-24

Females, 25-54

Females, 55+

$\begin{array}{rrrrrr}4.7 & 2.4 & 0.5 & 1.2 & 2.5 & 9.0 \\ 6.0 & 2.1 & 1.4 & 2.0 & 5.2 & 11.5 \\ 4.4 & \mathrm{~S} & \mathrm{~S} & 2.4 & 3.4 & 8.9 \\ 3.7 & 1.9 & 2.3 & 1.8 & 3.8 & 9.7 \\ 6.2 & 2.6 & 1.1 & \mathrm{~S} & 1.1 & 10.7 \\ 5.2 & 2.4 & \mathrm{~S} & \mathrm{~S} & \mathrm{~S} & 10.8\end{array}$

\section{Highest qualification}

No qualification

\begin{tabular}{rrrrrr}
6.4 & 1.2 & 0.9 & 2.4 & 4.6 & 11.0 \\
5.8 & 1.2 & $\mathrm{~S}$ & 1.8 & 3.3 & 9.4 \\
7.2 & 2.4 & 1.0 & 1.5 & 3.6 & 12.7 \\
3.7 & 2.1 & 0.5 & 1.0 & 2.0 & 7.5 \\
3.9 & 4.4 & 0.7 & $\mathrm{~S}$ & 1.3 & 9.4 \\
\hline
\end{tabular}

Higher school qualification

Vocational or trade qualification

Degree

$\mathrm{S}=$ Suppressed due to low sample size. 
Table 2: Personal characteristics of temporary and permanent employees

\begin{tabular}{|c|c|c|c|c|c|c|c|c|}
\hline & \multicolumn{4}{|c|}{ Type of temporary work } & \multirow[b]{2}{*}{$\begin{array}{c}\text { All } \\
\text { seasonal } \\
\text { employees }\end{array}$} & \multirow[b]{2}{*}{$\begin{array}{l}\text { Temporary } \\
\text { employees }\end{array}$} & \multirow[b]{2}{*}{$\begin{array}{c}\text { Permanent } \\
\text { employees }\end{array}$} & \multirow[b]{2}{*}{$\begin{array}{c}\text { All } \\
\text { employees }\end{array}$} \\
\hline & Casual & $\begin{array}{c}\text { Fixed- } \\
\text { term }\end{array}$ & $\begin{array}{c}\text { Temp } \\
\text { agency } \\
\text { worker }\end{array}$ & $\begin{array}{c}\text { Other } \\
\text { (mainly } \\
\text { seasonal \& } \\
\text { not further } \\
\text { defined) }\end{array}$ & & & & \\
\hline & \multicolumn{8}{|c|}{ Percentages unless indicated otherwise } \\
\hline Gender & & & & & & & & \\
\hline Male & 45.3 & 37.6 & 30.3 & 61.7 & 55.3 & 44.4 & 51.7 & 51.1 \\
\hline Female & 54.7 & 62.4 & 69.7 & 38.3 & 44.7 & 55.6 & 48.3 & 48.9 \\
\hline \multicolumn{9}{|l|}{ Age } \\
\hline Mean age & 34.6 & 36.5 & 35.0 & 36.9 & 35.1 & 35.5 & 39.4 & 39.0 \\
\hline \multicolumn{9}{|l|}{ Age group (y ears) } \\
\hline $15-24$ & 42.4 & 22.7 & 28.7 & 31.5 & 38.0 & 34.9 & 17.3 & 19.0 \\
\hline $25-34$ & 12.8 & 26.4 & 24.4 & 17.6 & 14.2 & 17.5 & 21.8 & 21.4 \\
\hline $35-44$ & 15.8 & 21.6 & 15.8 & 15.3 & 17.9 & 17.0 & 23.1 & 22.5 \\
\hline $45-54$ & 12.4 & 16.7 & 23.3 & 22.3 & 16.6 & 15.7 & 22.0 & 21.4 \\
\hline $55-64$ & 10.7 & 10.0 & $\mathrm{~S}$ & 9.8 & 9.9 & 10.4 & 13.4 & 13.1 \\
\hline $65+$ & 6.0 & 2.6 & $\mathrm{~S}$ & $\mathrm{~S}$ & 3.5 & 4.5 & 2.4 & 2.6 \\
\hline \multicolumn{9}{|l|}{ Gender by age group (years) } \\
\hline Males, $15-24$ & 23.2 & 13.1 & 10.7 & 23.6 & 24.0 & 19.5 & 8.9 & 9.9 \\
\hline Males, 25-54 & 13.6 & 19.3 & 16.6 & 27.9 & 21.7 & 17.0 & 34.9 & 33.2 \\
\hline Males, $55+$ & 8.5 & 5.2 & $\mathrm{~S}$ & 10.3 & 9.5 & 7.9 & 7.9 & 7.9 \\
\hline Females, 15-24 & 19.2 & 9.7 & 18.0 & 7.9 & 13.9 & 15.4 & 8.4 & 9.1 \\
\hline Females, 25-54 & 27.3 & 45.3 & 46.8 & 27.3 & 27.0 & 33.1 & 32.0 & 32.1 \\
\hline Females, 55+ & 8.2 & 7.4 & $\mathrm{~S}$ & $\mathrm{~S}$ & 3.8 & 7.1 & 7.8 & 7.7 \\
\hline \multicolumn{9}{|l|}{ Ethnic group } \\
\hline European only & 72.3 & 77.7 & 52.1 & 69.8 & 71.3 & 71.9 & 75.0 & 74.7 \\
\hline Māori only & 6.3 & 4.7 & 10.2 & 8.0 & 10.1 & 6.4 & 5.1 & 5.2 \\
\hline European / Māori & 4.4 & $\mathrm{~S}$ & $\mathrm{~S}$ & 8.9 & 6.1 & 4.6 & 4.8 & 4.8 \\
\hline Pacific peoples only & 2.8 & 3.0 & 12.6 & 5.3 & 5.4 & 3.9 & 3.7 & 3.7 \\
\hline Asian only & 10.5 & 9.2 & 12.8 & $\mathrm{~S}$ & 3.3 & 9.4 & 8.1 & 8.3 \\
\hline Other groups & 3.6 & 3.5 & $\mathrm{~S}$ & $\mathrm{~S}$ & $\mathrm{~S}$ & 3.9 & 3.3 & 3.4 \\
\hline \multicolumn{9}{|l|}{ Highest qualification } \\
\hline No qualification & 22.9 & 8.8 & 23.1 & 33.1 & 30.3 & 20.5 & 17.1 & 17.5 \\
\hline School Certificate/NCEA Level 1 & 9.5 & 4.2 & $\mathrm{~S}$ & 11.3 & 9.9 & 8.0 & 7.9 & 8.0 \\
\hline Higher school qualification & 20.9 & 14.5 & 20.5 & 16.1 & 19.1 & 19.2 & 13.6 & 14.1 \\
\hline Vocational or trade qualification & 24.7 & 29.7 & 22.2 & 25.7 & 24.7 & 26.0 & 33.3 & 32.5 \\
\hline Degree & 16.9 & 39.5 & 21.6 & $\mathrm{~S}$ & 10.0 & 20.9 & 20.9 & 20.9 \\
\hline Total & 100.0 & 100.0 & 100.0 & 100.0 & 100.0 & 100.0 & 100.0 & 100.0 \\
\hline Sample size & 600 & 280 & 90 & 180 & 370 & 1,170 & 10,740 & 11,940 \\
\hline Estimated population size $(000 \mathrm{~s})$ & 85.1 & 40.3 & 12.0 & 22.3 & 46.5 & 163.6 & $1,575.2$ & $1,743.2$ \\
\hline
\end{tabular}

$\mathrm{S}=$ Suppressed due to low sample size. 


\begin{tabular}{|c|c|c|c|c|c|c|c|c|}
\hline & \multicolumn{4}{|c|}{ Type of temporary work } & \multirow[b]{2}{*}{$\begin{array}{c}\text { All seasonal } \\
\text { employees }\end{array}$} & \multirow[b]{2}{*}{$\begin{array}{l}\text { Temporary } \\
\text { employees }\end{array}$} & \multirow[b]{2}{*}{$\begin{array}{l}\text { Permanent } \\
\text { employees }\end{array}$} & \multirow[b]{2}{*}{$\begin{array}{c}\text { All } \\
\text { employees }\end{array}$} \\
\hline & Casual & Fixed-term & $\begin{array}{c}\text { Temp } \\
\text { agency } \\
\text { worker }\end{array}$ & \begin{tabular}{|c|}
$\begin{array}{c}\text { Other } \\
\text { (mainly } \\
\text { seasonal } \& \\
\text { not further } \\
\text { defined) }\end{array}$ \\
\end{tabular} & & & & \\
\hline & \multicolumn{8}{|c|}{ Percentages unless indicated otherwise } \\
\hline \multicolumn{9}{|c|}{ Usual hours worked per week (main job) } \\
\hline Mean & 22.0 & 34.2 & 28.5 & 34.9 & 32.7 & 27.4 & 37.6 & 36.6 \\
\hline $0-19$ & 46.6 & 18.1 & 30.3 & 21.0 & 24.3 & 34.3 & 11.4 & 13.5 \\
\hline $20-39$ & 28.2 & 27.2 & 27.7 & 23.5 & 22.8 & 27.1 & 22.1 & 22.6 \\
\hline $40-49$ & 16.5 & 41.7 & 35.4 & 40.0 & 38.2 & 27.8 & 51.7 & 49.4 \\
\hline $50+$ & 4.2 & 12.6 & 2.3 & 11.9 & 12.3 & 7.4 & 14.0 & 13.4 \\
\hline Part-time (<30 hours) & 61.4 & 29.4 & 36.9 & 32.4 & 33.0 & 47.6 & 19.9 & 22.5 \\
\hline Full-time (30 hours + ) & 33.9 & 70.0 & 58.7 & 64.3 & 64.6 & 48.9 & 79.3 & 76.4 \\
\hline \multicolumn{9}{|l|}{ Occupation } \\
\hline managers & 2.2 & 7.7 & $\mathrm{~S}$ & $\mathrm{~S}$ & $\mathrm{~S}$ & 3.3 & 13.2 & 12.3 \\
\hline Professionals & 9.7 & 30.1 & 16.7 & $\mathrm{~S}$ & 5.7 & 14.5 & 18.0 & 17.7 \\
\hline $\begin{array}{l}\text { Technicians and associate } \\
\text { professionals }\end{array}$ & 10.8 & 20.3 & 12.0 & 9.6 & 11.1 & 13.0 & 12.0 & 12.1 \\
\hline Clerks & 10.7 & 17.7 & 26.4 & $\mathrm{~S}$ & 4.9 & 12.5 & 14.2 & 14.0 \\
\hline Service and sales workers & 29.1 & 5.5 & 14.4 & 12.1 & 10.8 & 19.9 & 16.7 & 17.1 \\
\hline Agriculture and fishery workers & 11.3 & 4.5 & $\mathrm{~S}$ & 22.3 & 27.4 & 10.4 & 3.6 & 4.3 \\
\hline Trades workers & 3.7 & 4.2 & $\mathrm{~S}$ & $\mathrm{~S}$ & $\mathrm{~S}$ & 3.8 & 9.1 & 8.6 \\
\hline Plant and machine operators and & & & & & & & 82 & 84 \\
\hline $\begin{array}{l}\text { assemblers } \\
\text { Elementary occupations }\end{array}$ & $\begin{array}{r}7.4 \\
14.8\end{array}$ & $\begin{array}{l}5.9 \\
4.1\end{array}$ & $\begin{array}{r}\text { S } \\
14.0\end{array}$ & $\begin{array}{l}34.5 \\
12.3\end{array}$ & $\begin{array}{l}26.0 \\
11.4\end{array}$ & $\begin{array}{l}11.0 \\
11.5\end{array}$ & $\begin{array}{l}8.2 \\
4.9\end{array}$ & $\begin{array}{l}8.4 \\
5.6\end{array}$ \\
\hline \multicolumn{9}{|l|}{ Employer's business type } \\
\hline Private sector & 61.1 & 42.5 & 70.9 & 71.5 & 67.5 & 59.0 & 67.3 & 66.5 \\
\hline Central government & 13.7 & 34.4 & $\mathrm{~S}$ & 9.8 & 12.6 & 17.6 & 15.7 & 15.9 \\
\hline Local government & 1.8 & 4.1 & $\mathrm{~S}$ & $\mathrm{~S}$ & $\mathrm{~S}$ & 2.1 & 2.0 & 2.0 \\
\hline Not for profit sector & 6.4 & 9.6 & 10.7 & 11.5 & 8.4 & 8.2 & 6.9 & 7.0 \\
\hline Not classified & 17.0 & 9.4 & 10.1 & 7.2 & 10.3 & 13.1 & 8.0 & 8.5 \\
\hline \multicolumn{9}{|l|}{ Size of ent erprise } \\
\hline 1-19 employees & 41.0 & 33.5 & 23.4 & 37.8 & 36.1 & 37.4 & 39.0 & 38.9 \\
\hline 20-99 employees & 13.9 & 18.2 & 18.0 & 20.5 & 18.5 & 16.3 & 20.8 & 20.3 \\
\hline 100-499 employees & 13.2 & 14.3 & 31.1 & 8.6 & 9.7 & 14.1 & 15.3 & 15.2 \\
\hline 500 employees or more & 14.7 & 24.5 & 18.9 & 25.2 & 25.2 & 19.1 & 16.9 & 17.1 \\
\hline Not classified & 17.1 & 9.4 & 8.7 & 7.8 & 10.5 & 13.1 & 8.0 & 8.5 \\
\hline \multicolumn{9}{|l|}{ Job tenure } \\
\hline Mean (years) & 2.3 & 2.5 & 1.2 & 6.4 & 4.1 & 2.9 & 5.9 & 5.6 \\
\hline Median (years) & 0.7 & 0.8 & 0.4 & 3.1 & 1.8 & 0.9 & 3.0 & 3.0 \\
\hline Less than 6 months & 46.3 & 42.4 & 51.2 & 21.5 & 36.9 & 41.7 & 13.2 & 15.9 \\
\hline 6 months to less than 1 year & 9.5 & 14.2 & 11.9 & 4.0 & 4.4 & 9.9 & 7.9 & 8.1 \\
\hline 1 to less than 3 years & 23.6 & 20.5 & 25.4 & 24.1 & 22.4 & 23.0 & 24.8 & 24.7 \\
\hline 3 to less than 10 years & 15.2 & 15.0 & 11.6 & 28.5 & 23.0 & 17.0 & 34.2 & 32.6 \\
\hline 10 years or more & 5.4 & 7.8 & 0.0 & 21.6 & 13.1 & 8.2 & 19.7 & 18.6 \\
\hline Total & 100.0 & 100.0 & 100.0 & 100.0 & 100.0 & 100.0 & 100.0 & 100.0 \\
\hline Sample size & 600 & 280 & 90 & 180 & 370 & 1,170 & 10,740 & 11,940 \\
\hline Estimated population size $(000 \mathrm{~s})$ & 85.1 & 40.3 & 12.0 & 22.3 & 46.5 & 163.6 & $1,575.2$ & $1,743.2$ \\
\hline
\end{tabular}

$\mathrm{S}=$ Suppressed due to low sample size. 
Table 4: Reasons for doing temporary work and preferences for permanent work

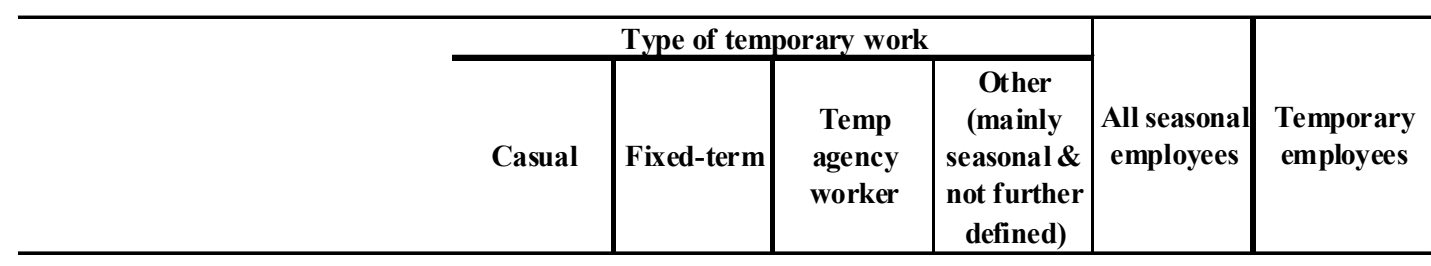

Reasons for doing temporary work

\begin{tabular}{|c|c|c|c|c|c|c|}
\hline Family reasons & 9.7 & 7.7 & 14.5 & 6.7 & 7.6 & 9.2 \\
\hline Educational reasons & 33.0 & 14.2 & 26.0 & 6.7 & 16.9 & 24.1 \\
\hline Health limitations & 2.1 & $\mathrm{~S}$ & $\mathrm{~S}$ & $\mathrm{~S}$ & $\mathrm{~S}$ & 1.4 \\
\hline Lifestyle reasons & 13.9 & 13.0 & 17.0 & 19.5 & 15.5 & 14.9 \\
\hline Financial reasons & 6.9 & 5.8 & $\mathrm{~S}$ & 22.4 & 17.6 & 8.5 \\
\hline \multicolumn{7}{|l|}{ Involuntary (only type of work } \\
\hline permanent) & 12.0 & 14.8 & 16.4 & 8.3 & 11.7 & 12.6 \\
\hline Other reasons & 27.7 & 41.9 & 29.4 & 46.5 & 38.8 & 34.0 \\
\hline \multicolumn{7}{|c|}{ Would prefer a job that is permanent/ongoing } \\
\hline All temporary employees & 36.5 & 49.1 & 47.2 & 33.5 & 35.6 & 40.1 \\
\hline Males & 34.6 & 49.6 & 54.4 & 38.9 & 37.8 & 39.7 \\
\hline Females & 38.0 & 48.8 & 44.0 & 25.0 & 32.9 & 40.4 \\
\hline $15-24$ years & 37.0 & 39.9 & 46.6 & 36.7 & 40.7 & 38.4 \\
\hline $25-54$ years & 44.2 & 55.0 & 48.5 & 35.7 & 35.2 & 47.2 \\
\hline 55 years and over & 16.4 & 35.5 & $\mathrm{~S}$ & $\mathrm{~S}$ & 22.7 & 20.5 \\
\hline Total & 100.0 & 100.0 & 100.0 & 100.0 & 100.0 & 100.0 \\
\hline Sample size & 600 & 280 & 90 & 180 & 370 & 1,170 \\
\hline Estimated population size $(000 \mathrm{~s})$ & 85.1 & 40.3 & 12.0 & 22.3 & 46.5 & 163.6 \\
\hline
\end{tabular}

$\mathrm{S}=$ Suppressed due to low sample size. 
Table 5: Employment outcomes of temporary and permanent employees

\begin{tabular}{|c|c|c|c|c|c|c|c|c|}
\hline & \multicolumn{4}{|c|}{ Type of temporary work } & \multirow[b]{2}{*}{$\begin{array}{c}\text { All seasonal } \\
\text { employees }\end{array}$} & \multirow[b]{2}{*}{$\begin{array}{l}\text { Temporary } \\
\text { employees }\end{array}$} & \multirow[b]{2}{*}{$\begin{array}{c}\text { Permanent } \\
\text { employees }\end{array}$} & \multirow[b]{2}{*}{$\begin{array}{c}\text { All } \\
\text { employees }\end{array}$} \\
\hline & Casual & Fixed-term & $\begin{array}{c}\text { Temp } \\
\text { agency } \\
\text { worker }\end{array}$ & \begin{tabular}{|c|}
$\begin{array}{c}\text { Other } \\
\text { (mainly } \\
\text { seasonal \& } \\
\text { not further } \\
\text { defined) }\end{array}$ \\
\end{tabular} & & & & \\
\hline & \multicolumn{8}{|c|}{ Dollars } \\
\hline \multicolumn{9}{|l|}{ Hourly earnings } \\
\hline Mean (\$) & 16.0 & 23.7 & 21.2 & 18.0 & 16.6 & 18.5 & 23.4 & 22.9 \\
\hline Mean - males (\$) & 16.0 & 24.0 & 20.2 & 18.6 & 17.4 & 18.4 & 25.6 & 25.0 \\
\hline Mean - females (\$) & 16.0 & 23.6 & 21.6 & 16.8 & 15.6 & 18.6 & 20.9 & 20.7 \\
\hline Median (\$) & 13.1 & 19.5 & 15.5 & 17.0 & 15.0 & 15.0 & 19.2 & 19.0 \\
\hline & \multicolumn{8}{|c|}{ Percentages } \\
\hline \multicolumn{9}{|l|}{ Hourly earnings } \\
\hline Below $\$ 15$ per hour & 54.6 & 24.5 & 35.9 & 40.6 & 42.9 & 43.5 & 24.3 & 26.1 \\
\hline$\$ 15-<\$ 25$ per hour & 26.0 & 36.7 & 33.9 & 38.4 & 36.1 & 31.2 & 40.4 & 39.5 \\
\hline$\$ 25$ or more per hour & 8.8 & 28.7 & 20.7 & 9.1 & 8.0 & 14.6 & 27.2 & 26.0 \\
\hline Earnings not specified & 10.7 & 10.2 & 9.5 & 11.9 & 13.0 & 10.7 & 8.1 & 8.4 \\
\hline \multicolumn{9}{|c|}{ Participation in employer-funded education or training during the past 12 months } \\
\hline All & 12.5 & 32.3 & 9.8 & 17.0 & 13.7 & 18.0 & 31.9 & 30.5 \\
\hline Males & 8.3 & 22.2 & $\mathrm{~S}$ & 13.4 & 8.8 & 12.1 & 33.1 & 31.3 \\
\hline Females & 15.9 & 38.4 & $\mathrm{~S}$ & 22.9 & 19.9 & 22.7 & 31.5 & 30.5 \\
\hline \multicolumn{9}{|c|}{ Time spent on employer-funded education or training during the past 12 months } \\
\hline 1 day or less & 3.0 & 12.2 & $\mathrm{~S}$ & 5.7 & 5.7 & 5.5 & 6.6 & 6.5 \\
\hline 2 to 5 days & 6.4 & 14.9 & $\mathrm{~S}$ & 7.3 & 5.2 & 8.7 & 15.0 & 14.4 \\
\hline 6 days or more & 3.1 & 5.2 & $\mathrm{~S}$ & $\mathrm{~S}$ & 2.9 & 3.8 & 10.3 & 9.7 \\
\hline \multicolumn{9}{|c|}{$\begin{array}{l}\text { Usual working time pattern (all jobs) } \\
\text { Usually works all hours at standard }\end{array}$} \\
\hline $\begin{array}{l}\text { times of working week } \\
\text { Usually works some hours at non- }\end{array}$ & 53.6 & 70.6 & 75.2 & 44.8 & 53.2 & 58.2 & 67.1 & 66.2 \\
\hline standard times of working week & 42.7 & 27.3 & 16.9 & 54.0 & 44.7 & 38.6 & 31.5 & 32.2 \\
\hline No usual working time pattern & 3.4 & $\mathrm{~S}$ & $\mathrm{~S}$ & $\mathrm{~S}$ & 2.2 & 3.1 & 1.5 & 1.6 \\
\hline \multicolumn{9}{|c|}{ Worked at non-standard times in the last 4 weeks } \\
\hline Evening work (7-11pm) & 33.3 & 31.7 & 15.8 & 18.3 & 22.6 & 30.2 & 30.1 & 30.1 \\
\hline Night work (11pm-5am) & 8.4 & 8.8 & $\mathrm{~S}$ & 6.5 & 11.6 & 9.5 & 10.1 & 10.0 \\
\hline Early morning work (5-7am) & 10.1 & 5.0 & 10.6 & 30.4 & 25.7 & 13.7 & 14.8 & 14.7 \\
\hline Weekend work & 52.8 & 40.3 & 30.3 & 64.4 & 58.6 & 49.9 & 46.4 & 46.7 \\
\hline $\begin{array}{l}\text { Total who worked at a non-standa } \\
\text { time }\end{array}$ & 63.4 & 48.9 & 42.6 & 77.7 & 70.2 & 60.3 & 55.5 & 55.9 \\
\hline Total & 100.0 & 100.0 & 100.0 & 100.0 & 100.0 & 100.0 & 100.0 & 100.0 \\
\hline Sample size & 600 & 280 & 90 & 180 & 370 & 1,170 & 10,740 & 11,940 \\
\hline Estimated population size $(000 \mathrm{~s})$ & 85.1 & 40.3 & 12.0 & 22.3 & 46.5 & 163.6 & $1,575.2$ & $1,743.2$ \\
\hline
\end{tabular}

$\mathrm{S}=$ Suppressed due to low sample size. 
Table 6: Estimates of the gap in average hourly earnings between temporary and permanent employees

\begin{tabular}{l|c|cc|cr}
\hline & $\begin{array}{c}\text { Unadjusted } \\
\text { difference in log } \\
\text { wage (temp- } \\
\text { permanent) }\end{array}$ & $\begin{array}{l}\text { Model 1 - Controls for } \\
\text { personal characteristics }\end{array}$ & $\begin{array}{c}\text { Model 2 - Controls for } \\
\text { personal and job } \\
\text { characteristics }\end{array}$ \\
\hline Males & & & Std Error & Coefficient & Error \\
All temporary workers & -0.301 & $-0.107 * * *$ & 0.028 & -0.007 & 0.022 \\
Casual & -0.414 & $-0.159 * * *$ & 0.039 & -0.023 & 0.029 \\
Fixed term & -0.090 & -0.022 & 0.057 & 0.012 & 0.050 \\
Seasonal & -0.312 & -0.058 & 0.037 & 0.032 & 0.033 \\
& & & & & \\
Females & -0.130 & $-0.072 * * *$ & 0.018 & -0.022 & 0.017 \\
All temporary workers & -0.254 & $-0.143 * * *$ & 0.022 & $-0.065 * * *$ & 0.022 \\
Casual & 0.114 & 0.034 & 0.035 & 0.040 & 0.031 \\
Fixed term & -0.043 & 0.021 & 0.067 & -0.018 & 0.067 \\
Temporary agency & -0.239 & $-0.096 * * *$ & 0.030 & -0.029 & 0.032 \\
Seasonal & & & & & \\
\hline
\end{tabular}

* Significant at the 90 percent confidence level. **Significant at the 95 percent confidence level.

***Significant at the 99 percent confidence level.

Table 7: Estimates of the gap in training probabilities between temporary and permanent employees

\begin{tabular}{l|c|c|c|}
\hline & $\begin{array}{c}\text { Unadjusted } \\
\text { difference in } \\
\text { training rates } \\
\text { (temporary- } \\
\text { permanent) }\end{array}$ & $\begin{array}{c}\text { Model 1 - } \\
\text { Controls for } \\
\text { personal } \\
\text { characteristics }\end{array}$ & $\begin{array}{c}\text { Model 2 - Controls } \\
\text { for personal and job } \\
\text { characteristics }\end{array}$ \\
\cline { 3 - 4 } $\begin{array}{l}\text { Males } \\
\text { All temporary workers }\end{array}$ & -0.210 & $-0.176^{* * *}$ & $-0.147^{* * *}$ \\
Casual & -0.247 & $-0.208^{* * *}$ & $-0.172^{* * *}$ \\
Fixed term & -0.110 & $-0.102 * *$ & $-0.101 * *$ \\
Seasonal & -0.243 & $-0.200 * * *$ & $-0.176^{* * *}$ \\
Females & & & \\
All temporary workers & -0.089 & $-0.082 * * *$ & $-0.056 * *$ \\
Casual & -0.158 & $-0.134 * * *$ & $-0.086 * *$ \\
Fixed term & 0.068 & 0.013 & -0.014 \\
Temporary agency & -0.222 & $-0.201 * * *$ & $-0.188^{* * *}$ \\
Seasonal & -0.116 & $-0.090 * *$ & -0.031
\end{tabular}

* Significant at the 90 percent confidence level. **Significant at the 95 percent confidence level. ${ }^{* * *}$ Significant at the 99 percent confidence level. 